\title{
Knowledge Of Princess Adoles About Personal Hygiene When Does The Princess Junior High School Students Know
}

\author{
Ida Susila*, Armenia Kastar \\ Vocational School of Lamongan Islamic University, Indonesia \\ *Idasusila18@gmail.com
}

\begin{abstract}
Personal hygiene is self-care which is done to maintain health both physically and psychologically. Self-care for adolescents during vaginal discharge needs to be taught as early as possible so that young women can avoid infectious diseases due to poor hygiene during vaginal discharge. The purpose of this study was to determine the personal hygiene knowledge of young women with vaginal discharge cases. Researchers used 50 respondents and all met the inclusion criteria. Sampling using total sampling. The variables studied were the characteristics of the respondents including age and education level. Meanwhile, personal hygiene knowledge variables include washing hands before touching the genitals, the correct way to wash the vagina, use of underwear, use of panty liners. For the case of leucorrhoea is the vaginal discharge experienced by the respondent. All variables were measured using a closed questionnaire and analyzed using descriptive analysis. The results of the research were that the age characteristics of the respondents were mostly 13 years old. The results of research on personal hygiene knowledge, most of the young women had poor knowledge of 23 respondents (46\%) about personal hygiene. For cases of vaginal discharge experienced, most of the vaginal discharge experienced was abnormal vaginal discharge, namely 27 respondents (54\%). Knowledge is not good due to limited access to information and facilitators at the educational institution. If left untreated, it will cause serious reproductive health problems. So that a facilitator is needed in order to solve this problem.

Based on the results of this study, health workers should work together with health agencies and schools to conduct extension activities in order to increase the knowledge of young women about vaginal discharge, especially the importance of personal hygiene during vaginal discharge.
\end{abstract}

Keywords : Knowledge, Vaginal Discharge, Personal Hygiene 


\section{STRADA Jurnal Ilmiah Kesehatan}

DOI: $10.30994 /$ sjik.v9i2.401

ISSN: 2252-3847 (print); 2614-350X (online)

Vol.9 No.2 November 2020 Page.936-943

\section{BACKGROUND}

Reproductive health is a state of well-being both physically, mentally, socially, which is intact in all matters relating to the function and role of the female reproductive system. Reproductive health knowledge should be carried out from adolescence, because a person will be able to recognize abnormalities in their own reproductive health as early as possible, especially regarding vaginal discharge (WHO, 2013).

Adolescence is a period of rapid growth and development both physically, psychologically and intellectually (Ministry of Health, 2015). At this time a teenager will increase his sex drive and will always seek more information about sex. Today's adolescents are more open and free so that they accept about free sex life outside of marriage while the knowledge about reproductive health and information related to reproductive health that they have is very little, both at school and in their family environment. Most Indonesian people who still adhere to the tradition consider taboo on matters related to reproductive health (Maulinda, 2010).

Teenagers are candidates for the next generation of the nation who have a big influence on all the actions they take. Adolescents are also the group of people who most often have problems ranging from social problems, behavior to reproductive health (Ministry of Health, 2015)

Whitish or flour albus is a symptom of excessive vaginal discharge or discharge, which causes wet underwear. The problem of vaginal discharge is often complained of by teenagers because it causes their own fear due to lack of education. In fact, vaginal discharge is something that normally occurs before menstruation as long as it is still within normal limits as long as it is clear and clear, odorless, does not itch and is not excessive. However, the problem of vaginal discharge that occurs in adolescents needs special attention. If the discharge during adolescence is allowed to cause serious illness (Pudiastuti, 2014).

Maintaining the health of the reproductive organs starts with personal hygiene, including vaginal hygiene, which aims to keep the vagina clean, normal, healthy and avoid the possibility of diseases including vaginal discharge. The ways that can be done for personal care of the vagina are: cleaning the vagina by washing the part between the vaginal lips carefully and slowly, how to wash the vagina properly from front to back, avoiding the use of fragrances and antiseptic soap continuously, because can damage the normal flora balance in the vagina, change your underwear 2 to 3 times a day and use clean, cotton underwear. Wash your hands before touching your vagina, do not use someone else's towel to dry your vagina, shave your vaginal hair at least once every 7 days and a maximum of 40 days to reduce moisture in the vagina, during menstruation use comfortable, soft pads, if using a public closet first flush the closet seat and dry it using toilet paper (Wulandari, 2011).

In the world, the incidence rate due to infection of the reproductive organs is estimated to be around 2.3 million per year, 1.2 million of them are found in developing countries, while the number of new cases is around 5 million per year and there are around 3 million in developing countries (Berman, 2009). Based on data in Indonesia, definite data on the number of people with ISR and STIs is not easy to obtain. Most of the patients with STIs are aged 15-29 years. Nearly 7 out of 10 people with STIs are 15-24 years old. The number of women in the world who have experienced vaginal discharge is around $75 \%$ while European women who experience vaginal discharge are $25 \%$ and based on data from the Population and Family Planning Board (BKKBN), for Indonesian women who experience vaginal discharge about $75 \%$. Bacterial Vaginosis (BV) is the most common cause of 


\section{STRADA Jurnal Ilmiah Kesehatan}

DOI: $10.30994 /$ sjik.v9i2.401

ISSN: 2252-3847 (print); 2614-350X (online)

Vol.9 No.2 November 2020 Page.936-943

pathological vaginal discharge (40\% -50\% of cases of vaginal infection) (Endang, 2007 in Tristanti, 2016). Pathological vaginal discharge is not only experienced by adult women but can also be experienced by young women. This is due to the limited information obtained by young women so that they do not pay attention to feminine hygiene so that it can cause vaginal discharge. The main cause of pathological vaginal discharge is infection (fungi, germs, parasites, and viruses). In addition to the main cause, pathological vaginal discharge can also be caused by a lack of care for young girls for genitalia, such as washing the vagina with stagnant water, using excessive rinses, using pants that do not absorb sweat, rarely changing underwear, not frequently changing sanitary napkins (Aulia, 2012 in Hutagol, 2013).

The data above shows that the incidence of vaginal discharge in women is quite high. This is closely related to humid weather conditions that cause women in Indonesia to be prone to vaginal discharge. Because in this condition, you will be susceptible to fungal infection. The discharge that occurs tends to be caused by the lack of awareness to maintain health, especially the health of the genetic organs (Dechacare, 2010). That is why it is very important for adolescents to maintain their personal hygiene, especially just before menstruation which causes the area of the external genital organs to become moist, which if not properly maintained will accelerate the process of bacterial reproduction.

Based on a preliminary study that has been conducted at the Education Institute "SMP Negeri 1 Maduran", Lamongan Regency. All young women in that place have experienced menstruation and have experienced vaginal discharge, even most of them often experience vaginal discharge. The purpose of this study was to describe how the knowledge of young women about personal hygiene in cases of vaginal discharge

\section{METHODS}

In this study, using a cross sectional design, the variables in the design were observed and measured at the same time as this research. This study uses a descriptive approach. The research was conducted at the Education Institute of "SMP Negeri 1 Maduran", Lamongan Regency in July 2020. The population in this study were all junior high school students in grade VII who were included in the inclusion criteria. According to the inclusion criteria, respondents met the inclusion criteria of 50 respondents. The inclusion criteria are: 1) willing to be a respondent, 2) 13-15 years old, c) already menstruating, d) present at the time of the research, e) being able to read, write, and understand information given either verbally or verbally. In this study, all members of the population studied, so no sampling was carried out in this study. The variables studied were: knowledge of young women about personal hygiene which included knowledge about washing their hands with soap before washing their hands, knowledge about how to wash the vagina properly, knowledge about wearing underwear, and knowledge about using pantyliners. In this study, the data used are primary data obtained using a questionnaire. The questionnaire was filled out by respondents. Data analysis was carried out descriptively and presented in the form of a frequency distribution table. 


\section{STRADA Jurnal Ilmiah Kesehatan}

DOI: $10.30994 /$ sjik.v9i2.401

ISSN: 2252-3847 (print); 2614-350X (online)

Vol.9 No.2 November 2020 Page.936-943

\section{RESULTS AND DISCUSSION}

\section{General Characteristics of Respondents}

The results of the research on the distribution of the characteristics of the respondents by age are described in the table below:

Table 1. Distribution of Respondents by Age

\begin{tabular}{lcc}
\hline Age & Total & Percentage $(\%)$ \\
\hline 13 years & 24 & 48 \\
14 years & 23 & 46 \\
15 years & 3 & 6 \\
\hline Total & 50 & 100 \\
\hline
\end{tabular}

Based on the table above, it is known that the most respondents at the age of 13 were 24 respondents (48\%). There are 3 respondents $(6 \%)$ who are 15 years old

\section{Personal Hygiene Knowledge}

The results of the research on the distribution of personal hygiene knowledge for young women in cases of vaginal discharge are described in table 2.

Table 2. Young Women Personal Hygiene Knowledge in Leucorrhoea Cases

\begin{tabular}{lcc}
\hline Knowledge & Amount & \% \\
\hline Good & 0 & 0 \\
Enough & 14 & 28 \\
Poor & 13 & 26 \\
Not Good & 23 & 46 \\
\hline Total & 50 & 100 \\
\hline
\end{tabular}

From the table above it can be seen that Most of the respondents had poor knowledge of 23 respondents $(46 \%)$ about personal hygiene. None of the respondents had good knowledge of personal hygiene. Meanwhile, 14 respondents (28\%) had sufficient knowledge and 13 respondents $(26 \%)$ were poor.

\section{Cases of Leucorrhoea Accompanied by Itching}

The results of the research on the distribution of vaginal discharge experienced by respondents accompanied by itching in the area of womanhood will be described in table 3.

Table 3. Respondents experience vaginal discharge accompanied by itching in the area of women

\begin{tabular}{lcc}
\hline & Amount & \% \\
\hline No & 11 & 22 \\
Yes & 39 & 78 \\
\hline Total & 50 & 100 \\
\hline
\end{tabular}

Based on the table above, it can be seen that most of the respondents experienced vaginal discharge accompanied by itching in the area of femininity, namely 39 respondents (78\%). There were 11 respondents $(22 \%)$ who did not have itchy discharge.

\section{Odor Accompanied Leucorrhoea}

The results of the research on the distribution of vaginal discharge experienced by respondents, whether it is accompanied by an unpleasant odor in the female area, are described in table 4. 


\section{STRADA Jurnal Ilmiah Kesehatan}

DOI: $10.30994 /$ sjik.v9i2.401

ISSN: 2252-3847 (print); 2614-350X (online)

Vol.9 No.2 November 2020 Page.936-943

Table 4. Experienced vaginal discharge accompanied by unpleasant odors in the area of females

\begin{tabular}{lcc}
\hline & Amount & \% \\
\hline No & 19 & 38 \\
Yes & 31 & 62 \\
\hline Total & 50 & 100 \\
\hline
\end{tabular}

Based on the table above, it can be seen that most of the respondents experienced vaginal discharge accompanied by an unpleasant odor, namely 31 respondents $(62 \%)$. While vaginal discharge without smell was 19 respondents $(38 \%)$.

\section{Whitish Color Experienced}

The results of the research on the distribution of vaginal discharge experienced by respondents are described in table 5.

Table 5. Whitish Color Experienced

\begin{tabular}{lcc}
\hline & Amount & \% \\
\hline White & 9 & 18 \\
Clear & 13 & 26 \\
Yellowish white & 28 & 56 \\
\hline Total & 50 & 100 \\
\hline
\end{tabular}

Based on the table above, it can be seen that most of the whitish colors experienced by respondents were yellowish white, which was 28 respondents $(56 \%)$, while 9 respondents $(18 \%)$ experienced white vaginal discharge and those who experienced clear vaginal discharge were 13 respondents $(26 \%)$.

\section{Analysis of cases of vaginal discharge in young women at SMP Negeri 1 Maduran}

The results of the research on the distribution of the case analysis for young women at SMP Negeri 1 Maduran experienced by respondents are described in table 6.

Table 6. Analysis of Leucorrhoea Cases in Young Women at SMP Negeri 1 Maduran

\begin{tabular}{lcc}
\hline $\begin{array}{c}\text { Discharge of } \\
\text { Cases }\end{array}$ & Amount & $\%$ \\
\hline Normal & 23 & 46 \\
Not normal & 27 & 54 \\
\hline Total & 50 & 100 \\
\hline
\end{tabular}

Based on the table above, it can be seen that most of the respondents experienced abnormal vaginal discharge, namely 27 respondents (54\%).

\section{Respondent Characteristics \\ Respondent Age}

Based on the research results, it is known that most of the respondents are at the age of 13 years. Age 13 years including early adolescence.

In 2012, out of 43.3 million adolescents aged 13-24 years in Indonesia behave unhealthy. This is based on Indonesian statistics. Indonesian adolescent girls of 23 million people are 13-24, 83.3\% have had sexual intercourse, which is one of the causes of vaginal discharge (Depkes RI, 2011) Age factor plays a role in a person acquiring knowledge. Youth ages 12-14 are early adolescence. The low knowledge of respondents 13 years of age is $48 \%$, compared to 14 years and 15 years of age can be caused by several factors. 


\section{STRADA Jurnal Ilmiah Kesehatan}

DOI: $10.30994 /$ sjik.v9i2.401

ISSN: 2252-3847 (print); 2614-350X (online)

Vol.9 No.2 November 2020 Page.936-943

The cognitive maturity factor is still lacking compared to the late adolescence. The information that adolescents get may differ from late adolescence.

The information obtained by adolescents may differ from the information obtained by other adolescents. The higher a person's age, the more his / her perceptive and intellectual powers develop (Notoatmodjo, 2007). Cognitive and psychological maturity will also increase. But adolescents aged 12-14 years are a period of early adolescence with a mindset and maturity that are not yet fully developed. In contrast to late adolescence (17-21 years) who reach cognitive maturity and gain life experiences of good and bad, where they develop their own moral code.

\section{Personal Hygiene Knowledge for Young Women}

Based on the results of the study, it was found that most of the respondents had bad knowledge about personal hygiene, namely 23 respondents (46\%) and none of them had good knowledge. Knowledge is something that can be known and is related to the teaching and learning process. Learning activities are influenced a lot from internal factors, such as motivation and external factors in the form of available information facilities, as well as socio-cultural conditions (Budiman and Riyanto, Agus., 2013).

A person's knowledge can be influenced by many things, one of which is education. Knowledge is closely related and related to education, which means that if a person has high education, his knowledge will also be high. According to Andira (2010), factors that can affect personal hygiene are: Body Image, an individual's image of himself greatly influences personal hygiene, for example due to physical changes so that individuals do not care about their own hygiene. Social practices, during childhood that are not independent in maintaining personal hygiene, so that personal hygiene can change. Socioeconomic status and personal hygiene require tools and materials such as soap, toiletries, all of which require money to provide them. Personal hygiene knowledge is very important because good knowledge can improve health status. Culture, in certain societies, says that if an individual is sick, he should not be washed. A person's habits, there are individual habits in the use of certain products in their personal care. Physical condition, in a certain condition an individual who is sick has less ability to take care of himself and needs help to do so.

The model of providing information about appropriate personal hygiene is by being explained directly and attached with pictures, this is done so that the information provided can be well received by female junior high school students. Because the young women said that if it was just an explanation without any pictures being shown, the students would only imagine.

The problem of the needs of young women about personal hygiene knowledge was not in accordance with the sources of information available in SMP. Based on the results of the interview that there was no source of information available at the school. In fact, there is a lot of information needed by young girls in school but not available, such as knowledge of personal hygiene, reproductive disease problems, methods of prevention and treatment.

According to Tanuwidjaya (2002), the level of knowledge of adolescents has an effect on their health if there are disorders or health problems in adolescents, so they can be resolved as soon as possible, so the level of knowledge is closely related. 


\section{STRADA Jurnal Ilmiah Kesehatan}

DOI: $10.30994 /$ sjik.v9i2.401

ISSN: 2252-3847 (print); 2614-350X (online)

Vol.9 No.2 November 2020 Page.936-943

\section{Young Women Leucorrhoea Case}

Leukorrhea is a problem that many women complain about from young age to old age. More than a third of patients who go to gynecology clinics in Indonesia complain of leukorrhea (fluor albus) and more than $80 \%$ of them are pathological. Pathological leukorrhea is caused by infection in the lower reproductive organs or in a more proximal area, which can be caused by gonococcal infection, trichomonas, candida, chlamydia, treponema, human papilloma virus, genital herpes. Transmission can occur through sexual contact. Pathological leukorrhea can also be caused by neoplasms / malignancies, foreign bodies, menopause, and erosion. Physiological leukorrhea can occur in newborns, during menarche, during ovulation, due to sexual stimulation, pregnancy, mood / stress, use of hormonal contraceptives, routine vaginal flushing (Sepdiana, 2019).

Epidemiologically, pathological leukorrhea can attack women from young, healthy reproductive age and old age and does not recognize the level of education, economy, and socio-culture, although this case is more common in women with low educational and socioeconomic levels. For women, this leukorrhea problem is very disturbing both in their daily life and in their relationship with their husbands. Discomfort, uneasiness at work, feeling inferior, worried about the possibility of cancer, publications or stories from neighbors or friends in the office about the consequences of leukorrhea causes a small proportion of women to seek help from a doctor but some are trying to find healing with traditional treatments such as washing with water betel and drinking herbal concoctions. The obstacle faced by women and doctors is the frequent occurrence of chronic cases due to the ignorance of women and inadequate therapy (Sepdiana, 2019).

Leucorrhoea (fluorine albus) is a very big problem for women. Most of the vaginal discharge is caused by the Candida fungi, although it can be caused by other microorganisms such as gonococus germs, genital herpes, and so on. Before puberty, women normally do not have vaginal discharge, unless there is infection or vaginal irritation. After puberty, estrogen (the female hormone) causes the vagina to produce secretions (fluids) that keep it moist and clean. This fluid comes out of the vagina as the vaginal body duh (leukorrhea). After menopause, estrogen levels decrease and vaginal discharge will also decrease (Sepdiana, 2019).

These results indicate that the incidence of vaginal discharge in young women is still quite high. This means that it is very important to handle the vaginal discharge experienced by young women. There are 2 types of vaginal discharge experienced by young women, namely normal vaginal discharge and abnormal vaginal discharge. The type of vaginal discharge that was mostly experienced by young women was abnormal vaginal discharge by 27 respondents (54\%). The results of this study support the research conducted by Astuti et al. (2008), with the result that there is a relationship between knowledge of vulva hygiene and the incidence of vaginal discharge in grade IX teenage girls at SMP 2 Ungaran. Maghfiroh's research, (2010) showed that there was a significant relationship between personal hygiene knowledge and handling of vaginal discharge in Darul Hasanah Kalikondang Islamic Boarding School students in Demak. The similarity of the results of this study concluded that knowledge has an important contribution in the formation of reproductive organ maintenance which in turn affects the incidence of vaginal discharge. Although vaginal discharge is a simple disease, in reality it is a difficult disease to cure. The population of women and almost all ages are at risk of developing this vaginal discharge almost 50\%. (Putu, 2009).

The results of this study concluded that knowledge of reproductive health had an effect on the incidence of vaginal discharge. The knowledge possessed by young women 


\section{STRADA Jurnal Ilmiah Kesehatan}

DOI: $10.30994 /$ sjik.v9i2.401

ISSN: 2252-3847 (print); 2614-350X (online)

Vol.9 No.2 November 2020 Page.936-943

affects the mindset which in turn will increase awareness to maintain reproductive health so that the incidence of vaginal discharge can be avoided. This implies that it is very important to provide reproductive health knowledge to adolescents which can be done through health education activities, counseling and counseling on reproductive health for young women. Parents also have an important role, especially if they have daughters, they need education and knowledge about reproductive health.

\section{CONCLUSION}

From the results of the discussion and data analysis, it can be concluded that the age characteristics of young women in SMP Negeri 1 Maduran, Lamongan Regency, are mostly 13 years old. For knowledge about personal hygiene in young girls at SMP Negeri 1 Maduran, Lamongan Regency has poor knowledge about personal hygiene. As for the cases of vaginal discharge experienced by young women at SMP Negeri 1 Maduran, Lamongan Regency, most of them are abnormal vaginal discharge.

\section{BIBLIOGRAPHY}

Agus, R. Budiman. 2013 Capita Selecta of Knowledge and Attitudes in Health Research. Salemba Medika: Jakarta

Andira, D. 2010. The ins and outs of women's reproductive health. Yogyakarta: A. PLUS BOOK

Astuti A.W.dkk 2008. Relationship of Vulva Hygiene Behavior with the incidence of vaginal discharge in young women in class ix SMP Unggaran Semaran Yogyakarta. Stikes Aisiyah Yogyakarta.

Aulia. 2012. Attacks typical of women's diseases most often occur. Yogyakarta, blue book

MOH, RI. 2011 Indonesian Health Demographic Survey 2011 MOHRI Survey

Hurlock E. 2007, Developmental Psychology of a Lifetime Approach About Life. Jakarta ; Erlangga

Ilmiawati, H. 2016 Personal Hygiene Behavior in Young Women Leucorrhoea Cases at the Nurul Haromain Islamic Education Institute "SMP Plus Fityani" Ngroto Village, Pujon District, Malang Regency. Airlangga University, Surabaya 2016

Ministry of Health. RI. 2015. Adolescent Reproductive Health.https: //www.kemkes.go.id/download.php? File = download / pusdatin / infodatin / infodatin $\% 20$ reproduction $\% 20$ adolescent-ed.pdf

Maghfiroh, K. 2010. The Relationship between Knowledge about personal hygiene and the handling of vaginal discharge in Darul Hasanah Kali Kondang Demak Islamic boarding school students in 2010, Muhammadiyah University, Semarang.

Maulinda. 2010. Relationship between Knowledge and Attitudes towards Adolescent Reproductive Health Education at SMPN 1 Margahayu. Padjadjaran University Thesis, Bandung

Notoatmodjo, S. 2007. Public Health Sciences, Basic Principles, Jakarta: Rineka Cipta Pudiastuti, Dewi Ratna. 2013. Deadly Diseases. Yogjakarta: Nuha Medika.

Putu. 2009. Prevalence of Leucorrhoea.http: //www.ziddu.com/download/5028081/atPrevalensi-kejadian.keputihan.zip accessed on 30 January 2016

Sepdiana, $\quad$ W. 2019.2 Flour Albus paper.http: //scholar.unand.ac.id/43353/2/2.\%20Bab\%201\%20\%28Penguluan\%29.pdf

Tanuwidjaya, S. 2003. General Concept of Growth and Development. Jakarta: EGC

Wulandari, A. 2011. The Right Way to Overcome Menstrual Pain. Yogyakarta: ANDI 